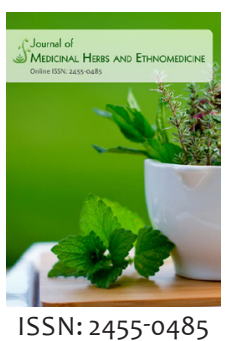

Received: January 10, 2020 Revised: February 18, 2021 Accepted: February 23, 2021 Published: February 27, 2021

*Corresponding Author: Tawseef Ahmad Mir, E-mail: tawseefbot@gmail. com

\section{A study on the use of medicinal plants for the treatment of diarrhoea and dysentery in Khag tehsil of Budgam District of Jammu and Kashmir, India}

\author{
Tawseef Ahmad Mir*, Rakesh Kumar Khare, Muatasim Jan \\ Centre of Research for Ethnobotany, Govt. Model Science College, Jiwaji University, Gwalior, \\ Madhya Pradesh - 474009, India
}

\begin{abstract}
People are using medicinal plants to alleviate diseases since the time immemorial. The present paper enumerates a total of 25 medicinal plants belonging to 19 families used for the treatment of diarrhoea and dysentery diseases in Khag tehsil of district Budgam, Jammu and Kashmir. Asteraceae was the dominant family. Leaves were found to be the dominant plant used for the preparation of herbal remedies. It was found that in this era of modern medicine, people are still relied on traditional medicine to get their primary health care. It was also revealed medicinal plants are under serious threat and needs to be conserved as so as to enjoy this legacy in the future too.
\end{abstract}

KEYWORDS: Medicinal plants, Diarrhoea, Dysentery, Khag, Budgam, Jammu and Kashmir

\section{INTRODUCTION}

Diarrhoea and dysentery have long been known as an important health problems in all age groups and are a major cause of sickness and death in rural communities of socioeconomically backward and developing, third-world countries. It may be infectious or non-infectious (de Hostos et al., 2011) with increase in frequency of passage of liquid faeces and alteration in stool character (amount and consistency). Infectious causative organism (virus, parasite or bacterium) spreads through contaminated food or drinking-water or from person to person as a result of poor hygiene (WHO, 2010) while different toxins, chronic diseases or antibiotics are contributed in non-infectious diarrhoea (NHDHHS, 2009). Clinically it involves both an increase in the motility of the gastrointestinal tract, along with increased secretion and reduced absorption of fluid and loss of electrolytes (particularly sodium) and water in the small and/or large intestine resulting in profuse watery stool output (Rang et al., 2003; Baldi et al., 2009). Globally, diarrhoea accounts for more than 5-8 million deaths annually, majority of whom are infants and children below 5 years old especially in developing countries (Gutierrez et al., 2008; Saralaya et al., 2010). 88\% of diarrhoea related deaths are caused by inadequate sanitation along with poor hygiene and clinically due to dehydration, which results from the loss of electrolytes in diarrhoeal stools (De Wet et al., 2010). Economically, diarrhoea is one of the major health challenges to humans as it causes loss of productive life due to premature mortality, disability and increased health-care costs (Guerrant et al., 2005). Usually, the treatment approach towards diarrhoea is non-specific, with the goal of reducing the distress and trouble of recurrent bowel movements (Suleiman et al., 2008). Oral rehydration therapy (ORT) is first line of treatment, when acute diarrhoea not control with ORT intravenous maintenance of fluid and electrolyte balance, antisecretory agents (bismuth compounds and octreotide); probiotics; anti-infectives (ciprofloxacin or levofloxacin) spasmolytic (loperamide, atropine, hyoscine) or other antidiarrhoeal agents ( $\alpha 2$-adrenergic receptor antagonists e.g. clonidine; calmodulin inhibitors e.g. zaldaride maleate) are used (Mims \& Curry, 2008). A global diarrhoeal disease control programme was constituted by the WHO (WHO, 1987). Along with modern drugs, the programme includes treatment based on indigenous practices as well as the evaluation of health education and prevention approaches. Keeping in view these conditions, present study was carried out in some tribal villages of Khag tehsil of district Budgam of Jammu and Kashmir to document the medicinal plants used for the treatment of diarrhoea and dysentery disorders.

Copyright: $\odot$ The authors. This article is open access and licensed under the terms of the Creative Commons Attribution License (http://creativecommons.org/licenses/by/4.0/) which permits unrestricted, use, distribution and reproduction in any medium, or format for any purpose, even commercially provided the work is properly cited. Attribution - You must give appropriate credit, provide a link to the license, and indicate if changes were made. 


\section{MATERIAL AND METHODS}

\section{Study Area}

Khag area of district Budgam of Jammu and Kashmir, is located some $55 \mathrm{kms}$ from district headquarters between $34^{\circ} .42^{\prime}$ to $34^{\circ} .50^{\prime} \mathrm{N}$ latitude and $74^{\circ} .24^{\prime}$ to $74^{\circ} .54^{\prime} \mathrm{E}$ longitude, at an altitude of $3000-5000 \mathrm{~m}$ above sea level (Figure 1). This area is located away from district headquarters in the lap of Himalayas. The temperature of the area ranges from $-7^{0} \mathrm{C}$ minimum in winters as it receives a good snowfall which goes to a maximum of $27^{\circ} \mathrm{C}$ in summers. The area is inhabited by people mostly of tribal communities such as Gujjar and Bakerwal. Being a border area and located at high altitude people are mostly dependent on indigenous medicine for their primary health care system. The traditional attire of the people of this area, with complex designs and embroidery reflects the rich culture and climate of the area.

\section{Ethnomedicinal data Collection and Identification}

The present study deals with the collection of the medicinal plants for the treatment of diarrhoea and dysentery among the local communities of Khag tehsil in district Budgam of Jammu and Kashmir. For the collection of medicinal plants from the study area, field surveys were performed between April to October 2020. Data was collected by using semi structured interviews and group discussions. Besides local tribal communities of Gujjar and Bakerwal, herbal healers and local knowledgeable persons were consulted during the course of study. Data collected was recorded in field notebook. Information regarding the use of medicinal plants by local people for the treatment diarrhoea and dysentery was collected in local language so as to get appropriate and reliable information. Collected plant species were dried, pressed and mounted on herbarium sheets of standard size following standard herbarium techniques (Miller \& Nyberg, 1995). Identification of the plants was conducted by Flora of Kashmir (Singh et al., 2002), Flora of British India (Hooker, 1879) and other concerned literature form Kashmir Himalaya (Singh \& Kachroo, 1994; Navchoo \& Kachroo, 1995). All the plants were given a specific collection number according to their collection from the field. Data obtained from the field is elaborated in the results section of this paper.

\section{RESULTS AND DISCUSSION}

The indigenous knowledge of plants used for the diarrhoea and dysentery collected from study area includes 25 medicinal plants belonging to 19 families (Tale 1). Asteraceae was found to be the dominant family being used by the local people with a species contribution of 3, followed Lamiaceae, Amaranthaceae, Plantaginaceae and Polygonaceae (2-species each), Mimosaceae, Acoraceae, Berberidaceae, Poaceae, Cyperaceae, Umbelliferae, Oxalidaceae, Plantanaceae, Punicaceae, Valerianaceae, Scrophulariaceae, Rhamnaceae, Brassicaceae and Moraceae (1-species each) (Table 2). Leaves were the dominant plant part used for the preparation of medicinal remedies with a species contribution of 8 , followed by Whole plant (6-species), Roots and Rhizome (3-species each), Fruits and Bark (2-species each) and Seeds (1-species) (Figure 2). All the plants with their botanical name, local name, family, part used, Habit, mode of application and collection number is described here under.

The use of plants for the existence of human being is as old practice as the human race itself. However, the accumulation of

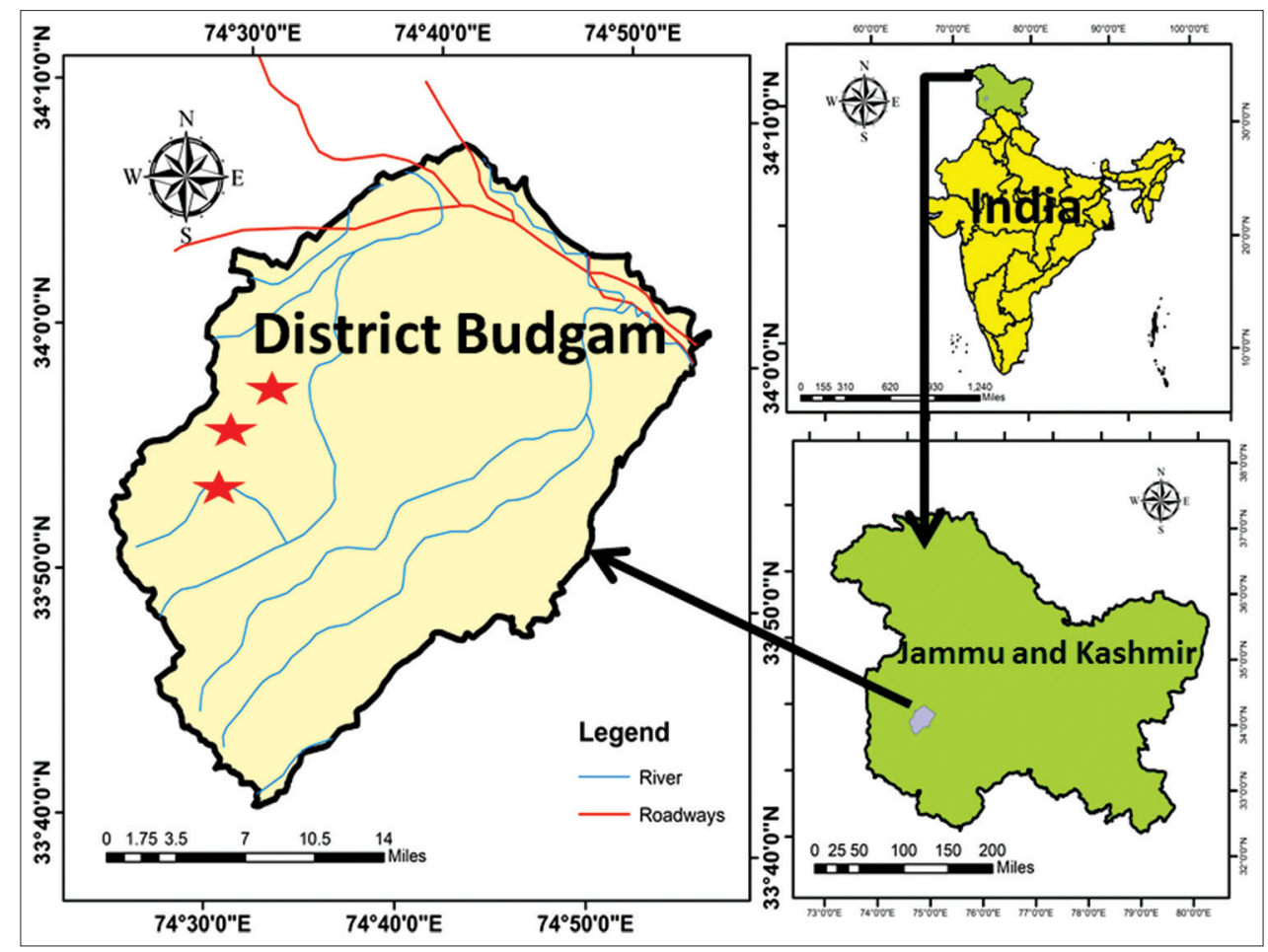

Figure 1: Map of the study area 
Table 1: Enumeration of plants used for the treatment of diarrhoea and dysentery in Khag area of Budgam, Jammu and Kashmir

\begin{tabular}{|c|c|c|c|c|c|c|c|c|}
\hline Sr. & $\begin{array}{l}\text { Botanical Name/Collection } \\
\text { number }\end{array}$ & Local Name & Family & Habit & Remedy & Part used & Mode of administration & Source \\
\hline 1 & $\begin{array}{l}\text { Achillea millefolium } \mathrm{L} \text {. } \\
\text { TM-003 }\end{array}$ & Pahal gassh & Asteraceae & Herb & Decoction & Whole plant & $\begin{array}{l}\text { Whole plant is boiled in water } \\
\text { and the decoction is used for } \\
\text { dysentery. }\end{array}$ & Wild \\
\hline 2 & $\begin{array}{l}\text { Robinia pseudoacacia L. } \\
\text { TM-007 }\end{array}$ & Kikar & Mimosaceae & Tree & Decoction & Leaves & $\begin{array}{l}\text { Decoction of leaves is used for } \\
\text { the treatment of diarrhoea } \\
\text { and also for the treatment of } \\
\text { dysentery by the local people. }\end{array}$ & Wild \\
\hline 3 & $\begin{array}{l}\text { Acorus calamus } \mathrm{L} \text {. } \\
\text { TM-002 }\end{array}$ & Vaigander & Acoraceae & Herb & & Rhizome & $\begin{array}{l}\text { The dried rhizome is crushed to } \\
\text { powder and is taken orally for } \\
\text { the treatment of dysentery and } \\
\text { chronic diarrhea. }\end{array}$ & Wild \\
\hline 4 & $\begin{array}{l}\text { Achyranthes aspera L. } \\
\text { TM-009 }\end{array}$ & Lainda & Amaranthaceae & Herb & Decoction & Whole plant & $\begin{array}{l}\text { Decoction of the whole plant is } \\
\text { taken orally for the treatment } \\
\text { of dysentery. }\end{array}$ & Wild \\
\hline 5 & $\begin{array}{l}\text { Amaranthus viridis } L \text {. } \\
\text { TM-001 }\end{array}$ & Liss & Amaranthaceae & Herb & Decoction & Leaves & $\begin{array}{l}\text { Leaves are crushed, then boiled } \\
\text { and decoction is taken orally } \\
\text { for diarrhea. }\end{array}$ & Wild \\
\hline 6 & $\begin{array}{l}\text { Berberis lycium Royle. } \\
\text { TM-011 }\end{array}$ & Kawdach & Berberidaceae & Shrub & Decoction & Leaves & $\begin{array}{l}\text { Dried leaves are crushed, } \\
\text { mixed with water and then } \\
\text { filtered through a cloth. The } \\
\text { extract obtained is used to cure } \\
\text { diarrhea. Decoction of leaves is } \\
\text { also taken for the treatment of } \\
\text { dysentery. }\end{array}$ & Wild \\
\hline 7 & $\begin{array}{l}\text { Capsella bursa-pastoris (L.) } \\
\text { Medik } \\
\text { TM-028 }\end{array}$ & Kralmond & Brassicaceae & Herb & Vegetable & Whole plant & $\begin{array}{l}\text { Whole plant is cooked as } \\
\text { vegetable and used for the } \\
\text { treatment of diarrhoea and } \\
\text { dysentery. }\end{array}$ & Wild \\
\hline 8 & $\begin{array}{l}\text { Cichorium intybus L. } \\
\text { TM-014 }\end{array}$ & Handh & Asteraceae & Herb & Vegetable & Whole plant & $\begin{array}{l}\text { Whole plant cooked as } \\
\text { vegetable is taken against } \\
\text { diarrhoea. }\end{array}$ & Wild \\
\hline 9 & $\begin{array}{l}\text { Conyza canadensis } \\
\text { Conquist. } \\
\text { TM-010 }\end{array}$ & Shal lutt & Asteraceae & Herb & Juice & Fruits & $\begin{array}{l}\text { Ripened fruits of the plant } \\
\text { are taken to make juice of it } \\
\text { and then used orally to cure } \\
\text { dysentery and diarrhoea by the } \\
\text { local people. }\end{array}$ & Wild \\
\hline 10 & $\begin{array}{l}\text { Cynodon dactylon } \mathrm{L} \text {. } \\
\mathrm{TM}-021\end{array}$ & Dramun & Poaceae & Herb & Powder & Whole plant & $\begin{array}{l}\text { Whole plant crushed into } \\
\text { powder is taken with water } \\
\text { for the treatment of chronic } \\
\text { dysentery and diarrhoea. }\end{array}$ & Wild \\
\hline 11 & $\begin{array}{l}\text { Cyperus rotundus } \mathrm{L} \text {. } \\
\text { TM-004 }\end{array}$ & Gashh & Cyperaceae & Herb & Paste & Rhizome & $\begin{array}{l}\text { The rhizomes are scraped and } \\
\text { pounded with green ginger and } \\
\text { mixed with honey is given in } \\
\text { dysentery. }\end{array}$ & Wild \\
\hline 12 & $\begin{array}{l}\text { Daucus carota L. } \\
\text { TM-006 }\end{array}$ & Gajar & Umbelliferae & Herb & Juice & Roots & $\begin{array}{l}\text { Juice obtained from the } \\
\text { plant roots is taken twice a } \\
\text { day for about three days to } \\
\text { cure dysentery and weakness } \\
\text { occurred by dysentery. }\end{array}$ & Cultivated \\
\hline 13 & $\begin{array}{l}\text { Ficus carica L. } \\
\text { TM-032 }\end{array}$ & Anjeer & Moraceae & Tree & Decoction & Fruits & $\begin{array}{l}\text { Decoction or juice of fruit is } \\
\text { used for diarrhoea. }\end{array}$ & Cultivated \\
\hline 14 & $\begin{array}{l}\text { Mentha arvensis L. } \\
\text { TM-024 }\end{array}$ & Pudni & Lamiaceae & Herb & Powder & Whole plant & $\begin{array}{l}\text { Whole plant is crushed, } \\
\text { made into powder and taken } \\
\text { with curd for the treatment } \\
\text { of prolonged dysentery and } \\
\text { diarrhoea. }\end{array}$ & Cultivated \\
\hline 15 & $\begin{array}{l}\text { Mentha longifolia L. } \\
\text { TM-026 }\end{array}$ & Jangli pudni & Lamiaceae & Herb & Powder & Leaves & $\begin{array}{l}\text { The dried leaves are powdered } \\
\text { and used in diarrhea and } \\
\text { dysentery. }\end{array}$ & Wild \\
\hline 16 & $\begin{array}{l}\text { Oxalis corniculata L. } \\
\text { TM-019 }\end{array}$ & Chuk chen & 0xalidaceae & Herb & Powder & Leaves & $\begin{array}{l}\text { Plant leaves are crushed, made } \\
\text { into powder and taken with } \\
\text { water for the treatment of } \\
\text { dysentery. }\end{array}$ & Wild \\
\hline
\end{tabular}


Table 1: (Continued)

\begin{tabular}{|c|c|c|c|c|c|c|c|c|}
\hline Sr. & $\begin{array}{l}\text { Botanical Name/Collection } \\
\text { number }\end{array}$ & Local Name & Family & Habit & Remedy & Part used & Mode of administration & Source \\
\hline 17 & $\begin{array}{l}\text { Plantago major } \mathrm{L} \text {. } \\
\text { TM-020 }\end{array}$ & Bodd gull & Plantaginaceae & Herb & Powder & Seeds & $\begin{array}{l}\text { Seeds are crushed and taken } \\
\text { with milk for the treatment of } \\
\text { dysentery. }\end{array}$ & Wild \\
\hline 18 & $\begin{array}{l}\text { Plantago lanceolata L. } \\
\text { TM-025 }\end{array}$ & Gull & Plantaginaceae & Herb & Decoction & Leaves & $\begin{array}{l}\text { Extract is obtained from leaves } \\
\text { and is taken for the treatment } \\
\text { of diarrhoea by rural people. }\end{array}$ & Wild \\
\hline 19 & $\begin{array}{l}\text { Platanus orientalis L. } \\
\text { TM-018 }\end{array}$ & Boen & Plantanaceae & Tree & Decoction & Bark & $\begin{array}{l}\text { Bark decoction is obtained } \\
\text { and taken for diarrhoea and } \\
\text { dysentery disorders. }\end{array}$ & Wild \\
\hline 20 & $\begin{array}{l}\text { Polygonum bistorta L. } \\
\text { TM-029 }\end{array}$ & - & Polygonaceae & Herb & Decoction & Roots & $\begin{array}{l}\text { Root decoction is taken in case } \\
\text { of diarrhoea and dysentery. }\end{array}$ & Wild \\
\hline 21 & $\begin{array}{l}\text { Persicaria hydropiper L. } \\
\text { TM-033 }\end{array}$ & - & Polygonaceae & Herb & Juice & Roots & $\begin{array}{l}\text { The juice obtained from the } \\
\text { roots is used for diarrhea and } \\
\text { dysentery }\end{array}$ & Wild \\
\hline 22 & $\begin{array}{l}\text { Punica granatum L. } \\
\text { TM-037 }\end{array}$ & Anar & Punicaceae & Herb & Juice & Leaves & $\begin{array}{l}\text { The juice of fruits is used } \\
\text { against dysentery. }\end{array}$ & Cultivated \\
\hline 23 & $\begin{array}{l}\text { Valeriana jatamansi Jones } \\
\text { TM-035 }\end{array}$ & Mushkbala & Valerianaceae & Herb & Decoction & Rhizome & $\begin{array}{l}\text { Decoction of rhizome is } \\
\text { used against dysentery and } \\
\text { diarrhoea. }\end{array}$ & Wild \\
\hline 24 & $\begin{array}{l}\text { Verbascum thapus L. } \\
\text { TM-044 }\end{array}$ & Wantamook & Scrophulariaceae & Herb & Decoction & Leaves & $\begin{array}{l}\text { Extract obtained from leaves of } \\
\text { is taken against dysentery and } \\
\text { diarrhoea. }\end{array}$ & Wild \\
\hline 25 & $\begin{array}{l}\text { Zizyphus jujuba Mill. } \\
\text { TM-049 }\end{array}$ & Ber & Rhamnaceae & Tree & Paste & Bark & $\begin{array}{l}\text { The macerated bark is mixed } \\
\text { with milk and honey, and is } \\
\text { taken for the treatment of } \\
\text { diarrhea and dysentery. }\end{array}$ & Wild \\
\hline
\end{tabular}

Table 2: Species contribution of reported families from Budgam, Jammu and Kashmir

\begin{tabular}{|c|c|c|c|}
\hline Family & Plant species & Number of species & Percentage \\
\hline Asteraceae & $\begin{array}{l}\text { Achillea } \\
\text { millefolium, } \\
\text { Cichorium intybus, } \\
\text { Conyza canadensis }\end{array}$ & 3 & 12 \\
\hline Lamiaceae & $\begin{array}{l}\text { Mentha arvensis, } \\
\text { Mentha longifolia }\end{array}$ & 2 & 8 \\
\hline Amaranthaceae & $\begin{array}{l}\text { Amaranthus viridis, } \\
\text { Achyranthes aspera }\end{array}$ & 2 & 8 \\
\hline Plantaginaceae & $\begin{array}{l}\text { Plantago major, } \\
\text { Plantago lanceolata }\end{array}$ & 2 & 8 \\
\hline Polygonaceae & $\begin{array}{l}\text { Polygonum } \\
\text { bistorta, Persicaria } \\
\text { hydropiper }\end{array}$ & 2 & 8 \\
\hline Mimosaceae & $\begin{array}{l}\text { Robinia } \\
\text { pseudoacacia }\end{array}$ & 1 & 4 \\
\hline Acoraceae & Acorus calamus & 1 & 4 \\
\hline Berberidaceae & Berberis lycium & 1 & 4 \\
\hline Poaceae & Cynodon dactylon & 1 & 4 \\
\hline Cyperaceae & Cyperus rotundus & 1 & 4 \\
\hline Umbelliferae & Daucus carota & 1 & 4 \\
\hline Oxalidaceae & Oxalis corniculata & 1 & 4 \\
\hline Plantanaceae & Platanus orientalis & 1 & 4 \\
\hline Punicaceae & Punica granatum & 1 & 4 \\
\hline Valerianaceae & Valeriana jatamansi & 1 & 4 \\
\hline Scrophulariaceae & Verbascum thapus & 1 & 4 \\
\hline Rhamnaceae & Zizyphus jujuba & 1 & 4 \\
\hline Brassicaceae & $\begin{array}{l}\text { Capsella bursa } \\
\text { pastoris }\end{array}$ & 1 & 4 \\
\hline Moraceae & Ficus carica & 1 & 4 \\
\hline
\end{tabular}

knowledge of plant use evolved with human civilization through the experimental use of plants, generation after generation.

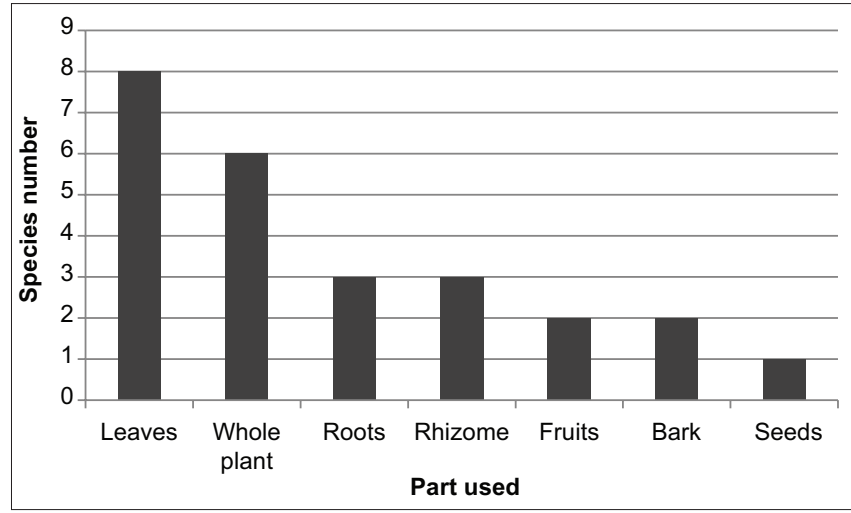

Figure 2: Species contribution for part used

People would have remained exposed to epidemic, endemic and chronic diseases, besides acute ailments (Hamayun, 2003). It has been estimated that $80 \%$ of the world's population is dependent on traditional medicine for their primary health care needs (Rai et al., 2000; Anzar et al., 2007; Jan et al., 2020). Herbal medicines are being used because people are not able to get allopathic medicines. In Khag area of Budgam district of Jammu and Kashmir local people have remarkable detailed knowledge of species identity and medicinal usage. However, the anthropogenic unsustainable activities such as deforestation, habitat destruction, urbanization etc. may pose a serious threat to the important medicinal species. Hence, priority should be given to initiation of conservation action works with appropriate measures involving local participation, implementation of awareness activities with integrated approach for sustainable use of medicinal plants. 


\section{CONCLUSION}

Herbal medicines are the backbone of traditional health care system as it is the primary health care facility being used by most of the people around the world. Medicinal plants are not only used in developing countries but they are making their popularity in industrialized countries as well because of their negligible side effects and cost effective condition. But due to urbanization and modernization this asset is on the verge of extinction. So there is dire need to conserve it before it will get vanished. Therefore documentation of the plants provides a way towards the conservation of this valuable resource. In addition, it is needed to check the phytochemical and pharmacological properties of medicinally important plants.

\section{ACKNOWLEDGMENTS}

Authors are thankful to Government Model Science College, Jiwaji University, Gwalior, for providing us the necessary facilities for our work. Authors are also thankful to local population of the study area for sharing their knowledge.

\section{REFERENCES}

Anzar, A. A., Rashid, I., Reshi, Z., Dar, G. H., \& Wafai, B. A. (2007). The Alien Flora of Kashmir Himalaya. Biological Invasions, 9, 262 -292. https:// doi.org/10.1007/s10530-006-9032-6

Baldi, F., Bianco, M. A., Nardone, G., Pilotto, A., \& Zamparo, E. (2009). Focus on acute diarrhoeal disease. World Journal of Gastroenterology, 15(27), 3341-3348. https://doi.org/10.3748/wjg.15.3341

de Hostos, E. L., Choy, R. K., \& Nguyen, T. (2011). Developing novel antisecretory drugs to treat infectious diarrhea. Future Medicinal Chemistry, 3(10), 1317-1325.

de Wet, H., Nkwanyana, M. N., \& van Vuuren, S. F. (2010). Medicinal plants used for the treatment of diarrhoea in northern Maputaland, KwaZuluNatal Province, South Africa. Journal of ethnopharmacology, 130(2), 284-289. https://doi.org/10.1016/j.jep.2010.05.004

Guerrant, R. L., Oria, R., Bushen, O. Y., Patrick, P. D., Houpt, E., \& Lima, A. A. M. (2005). Global impact of diarrhoeal diseases that are sampled by Traveller: the rest of the Hippopotamus. Clinical Infectious Diseases, 4, 5524-5530. https://doi.org/10.1086/432946

Gutiérrez, R. M., Mitchell, S., \& Solis, R. V. (2008). Psidium guajava: a review of its traditional uses, phytochemistry and pharmacology. Journal of ethnopharmacology, 117(1), 1-27. https://doi.org/10.1016/j. jep.2008.01.025

Hamayun, M. (2003). Ethnobotanical studies of some useful shrubs and trees of District Buner, NWFP, Pakistan. Journal of Ethnobotanical Leaflets, 11, 1-8.

Hooker, J. D. (1879). The Flora of British India. (Vol. 2). Ashford, Kent, England: L. Reeve and Co (pp. 78-99).

Jan, M., Mir, T. A., \& Khare, R. K. (2020). Indigenous medicinal usage of family Solanaceae and Polygonaceae in Uri, Baramulla, Jammu and Kashmir. Journal of Medicinal Herbs and Ethnomedicine, 6, 86-89. https://doi.org/10.25081/jmhe.2020.v6.6492

Miller, A. G., \& Nyberg, J. A. (1995). Collecting Herbarium Vouchers. Edinburgh EH3 5LR, U.K: Royal Botanic Garden (pp. 561-573).

Mims, B. C., \& Curry, J. C. E. (2008). Constipation, diarrhoea, and irritable bowel syndrome. In M. Brown, J. Malley, R. Pancotti \& R. Y. Brown (Eds.), Pharmacotherapy Principles and Practice (pp. 307-321) USA: McGraw-Hill.

Navchoo, I. A., \& Kachroo, P. (1995). Flora of Pulwama, Kashmir. Dehradun, Uttarakhand: Bishen Singh and Mahendra Pal Singh.

New Hampshire Department of Health and Human Services (NHDHHS). (2009). Diarrhoea (Infectious Diarrhoea). Disease handbook for childcare providers. Division of Public Health Services, Communicable Disease Control Section. Revised April, 2009. [www.dhhs.nh.gov/ dphs/cdcs/documents/diarrhoea.pdf] (accessed 31.12.14).

Rai, L. K., Prasad, P., \& Sharma, E. (2000). Conservation threats to some important plants of the Sikkim Himalaya, Biological Conservation, 93, 27-33. https://doi.org/10.1016/S0006-3207(99)00116-0

Rang, H. P., Dale, M. M., Ritter, J. M., Moore, \& P. K. (2003).The gastrointestinal tract, Pharmacology (pp. 367-379). (5 $5^{\text {th }}$ Eds.). Edinburgh. Churchill Livingstone.

Saralaya, M. G., Patel, P., Patel, M., Roy, S. P., \& Patel, A. N. (2010). Antidiarrhoeal activity of methanolic extract of Moringa oleifera Lam roots in experimental animal models. International Journal of Pharmaceutical Research, 2(2), 35-39.

Singh, J. B., \& Kachroo, P. (1994). Forest Flora of Pir Panjal Range: North Western Himalaya. Dehradun, India: Bishen Singh Mahendra Pa Singh.

Singh, N. P., Singh, D. K., Uniyal, B. P. (2002). Flora of Jammu \& Kashmir: Pteridophytes Gymnosperms and Angiosperms (Vol. 1). New Delhi, India: Botanical Survey of India.

Suleiman, M. M., Dzenda, T., \& Sani, C. A. (2008). Antidiarrhoeal activity of the methanol stem-bark extract of Annona senegalensis Pers. (Annonaceae). Journal of Ethnopharmacology, 116, 125-130. https:// doi.org/10.1016/j.jep.2007.11.007

WHO. (1987). Report of the Second Meeting of Directors of WHO Collaborating Centres for Traditional Medicine. WHO, Geneva, Switzerland. (Document WHO/TRM/88.1).

World Health Organization. (2013). Integrated global action plan for the prevention and control of pneumonia and diarrhoea (GAPPD) 12 April 2013 http://www.who.int/topics/diarrhoea/en/ 